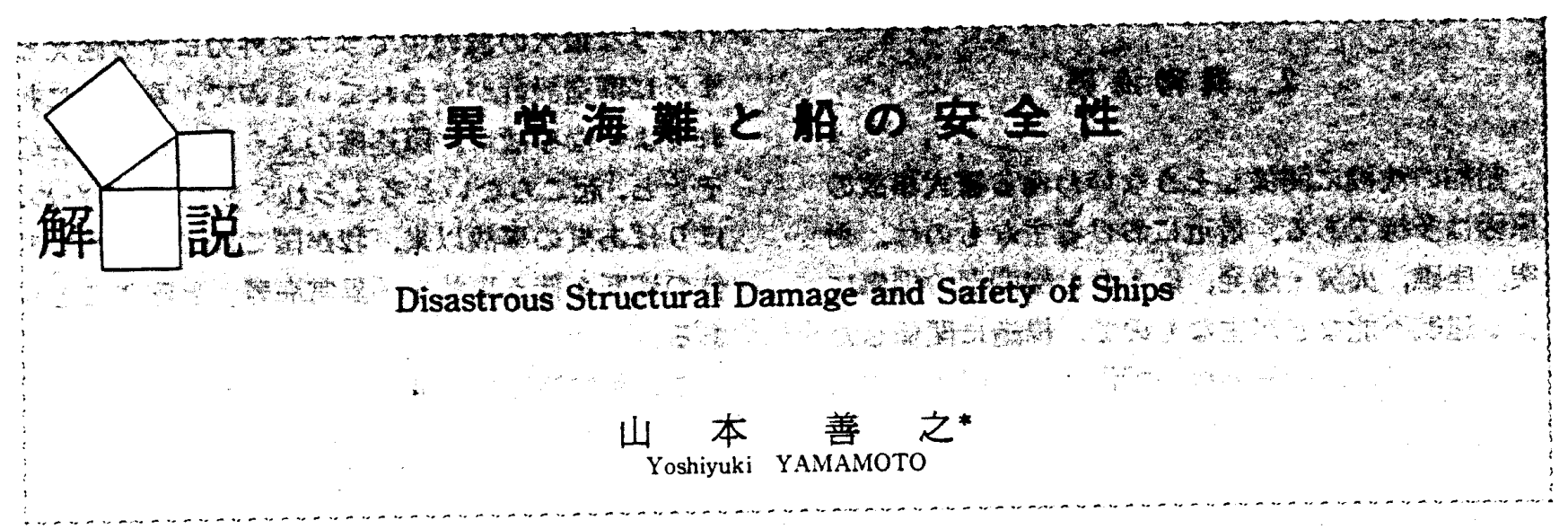

Key Words: Ship, Safety, Waves, Slamming, Ship Strength, Ship Operation

\section{1. 魔の野島崎沖}

昭和 41 年早春, 相ついで起こった大形ジェット 機の慜落事故は，その1週間後に渡米をひかえて いた著者を恐怖のどん底につき落とした。このよ うな連続事故は，全く異なる原因によるものであ るにもかかわらず，その奥底には何かの関連があ ろ. 1 週間ほどの間に，東京湾で全員 133-名妩亡， 羽田で 64 名死亡, 富土山で全員 124 名死亡と, 3 機の大形機の事故によって 300 名をこえる犠牲者 を出した。

その 3 年のち昭和 44 年 1 月 5 日ぼりばあ丸 (33768 総トン), 翌 45 年 2 月 9 日かりふおるにあ 丸（34001 総トン）という2 隻の大形船が, 真二 つに折れるとか；船首部に大損傷をうけて，いわ ゆる野島崎沖で沈没した. 前者では乗組員 33 名中 31 名, 後者では 29 名中 7 名の犠牲者を出した。 の場合の犠牲者は船員といういわゆるプロである が，失わ机た命には代わりはない。これに対して， 大形船の前部の構造を補強することと, 荒れた海 域においては, 船の速力を減ずるとか, 波に対す る相対的な方向を変えるといういわゆる運航マ二 ュアルを作成し，実施することにより小康を保っ ていた。

昭和 55 年末から翌年初めにかけての8 日間に, やはり野島崎沖の海域で5隻もの大形船（ほかに

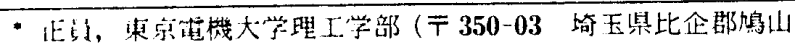
旷大'保们坂).

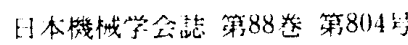

中形船 1 隻) が相ついで沈没した。このうちの 1 隻が我が国の尾道丸（33833 総トン）で，昭和 55 年 12 月 30 日遭難し, 船首が切断・沈没した。中 央部はなお浮いていたため, 乗組員 29 名は全員救 助されたが，船体はグアム島へえい航中翌年 2 月 11 日に沈没した（図1）。

この 5 隻のうち尾道丸を含む 2 隻の乗組員は救 助されたが，他の 3 隻の乗組員は船と運命をとも にした，損鹪報告のあった 4 隻はすべて船首部に 構造上の大損傷を受けたという。

大形船をつぎつぎに沈没させる冬の野島崎沖は 異常な波浪の発生する「魔の海域」であろうか。 大形ジェット機や大形船のように，高級なシステ 么は計画時にいろいろな角度から安全性が確認さ れている。事故は，その安全性の検討からはずれ た状況のもとで起こったのであろう.したがって， 事故の原因がわか机ば，その種の事故の再発を防 ぐための方策が得られるはずである。

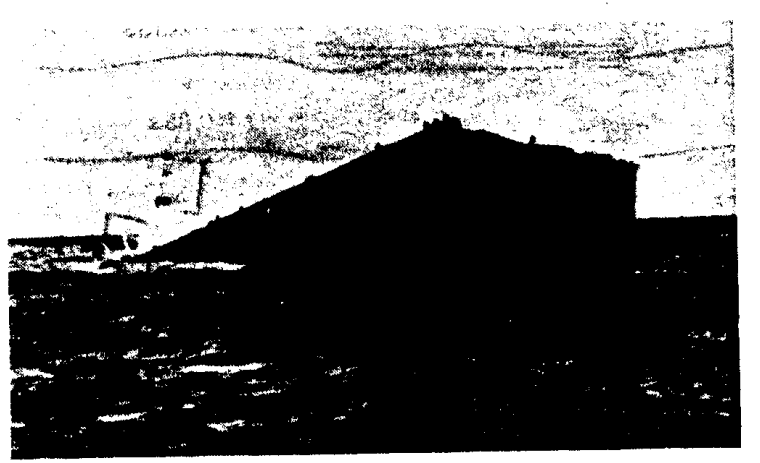

図 1 沈没する尾道丸 


\section{2. 異常海 難}

船舶の沈没に関係しそうないわゆる重大事故の 原因は多様である，最近における主なものは，衝 突，座礁，火災・爆発，舵を含む機関部の損倡に よる運航不能などが主なもので，構造に関係した ものとして注，船側外板の損傷に上る浸水，出入 ロのドアやハッチカバーの破損などがあるが，航 海中の船が折れるというような事故は極めてまれ である。著者が知るかきりりでは，材料に原因のあ るものを除くと，ぼりばあ丸の事故以前には，イ ギリス駆逐艦 1 婁（明治 33 年）と日本の駆逐艦 2 隻 (昭和 10 年) があるだけである。船体は, 起こ

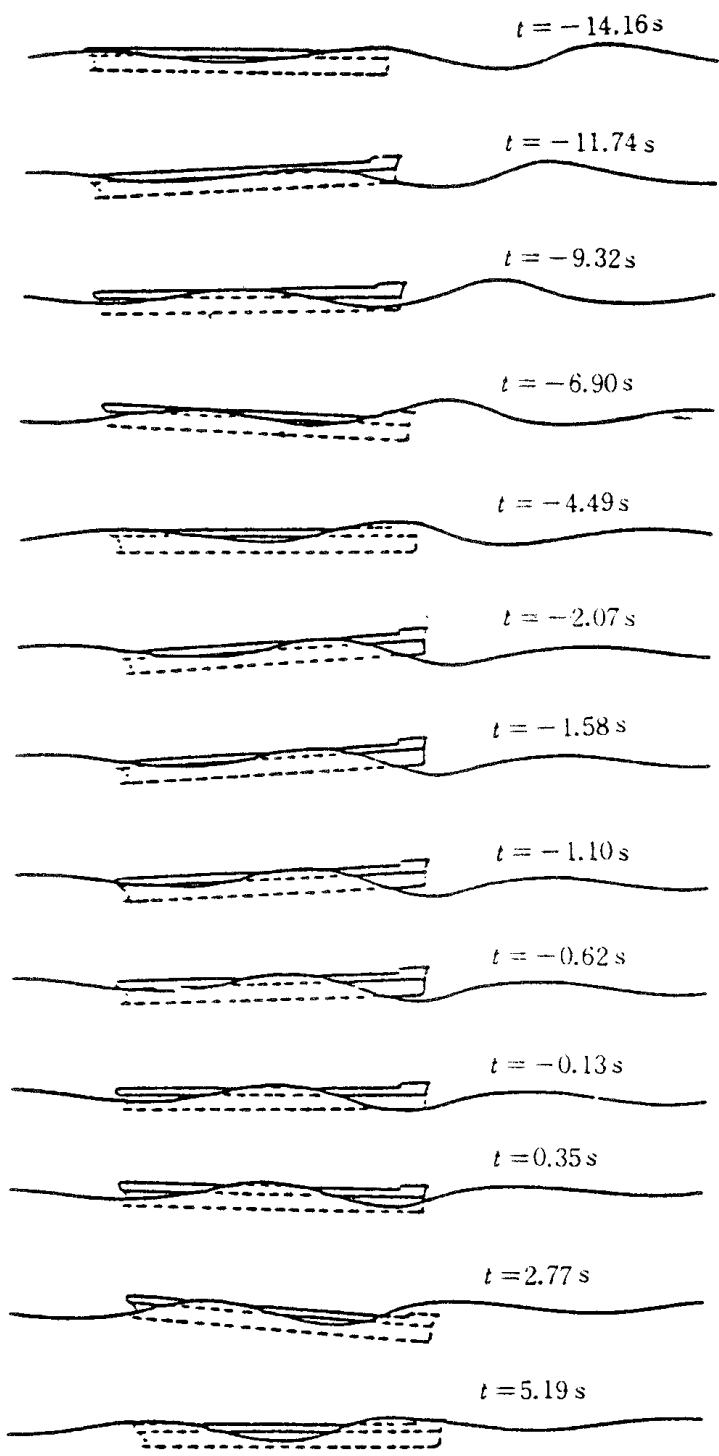

図 2 尾道丸の波浪中の挙動 $(t=0 \mathrm{~s}$ に船首に スラミング発生）
りそうな最大の波の中でうける外力に十分耐える ように構造設計がなされているので，真二つに折 れるような事故は，駆逐艦のように細長い船をの ぞくと，起こらないと考えられてきた，そのため， ほりばあ丸の事故以来，我が国ではこのような船 体の切断を伴う事故を「異常海難」と呼ふことが ある。

この異常海難には波浪の状況と船の構造強度が 関係しており，船の構造寸法決定法が適切でなか つたのではないかという疑問も提出され，大きな 社会問題になった。

ぽりばあ丸の生存者には運航を担当する甲板部 の船員がいなかったため，同船が遭遇した波の状 況を明らかにすることかできなかった。尾道丸の 場合はその遭遇した波浪に関する詳しい説明が， 船長に上ってなされており，また救助に向かった 船からの情報もあり，波に対する信頼すべき資料 が得られた。その結果，波高は予想されたより低 く，有義波高（目視波高の $1 / 3$ 最大平均に相当）住 8〜9 $\mathrm{m}$ とされ，異常に高い波が発生していたとは いいがたい。従来の理論によると，波によって船 に生ずる曲げモーメントはほほ波高に比例すると 考えられていたので，その理論に上ると，本船が 異常に弱かったのではないかという推論が可能に なる。

一方，この上うな事実は，従来の理論の正当性 を疑う根拠にもなる。従来，このような大形船が 積荷を満載して深い喫水で航海しているときは, その船底が露出することはないと考えられてい た。そ机を否定すると，船首部の船底が露出して 水に再突入するとき，水面に船底が衝突し，いわ

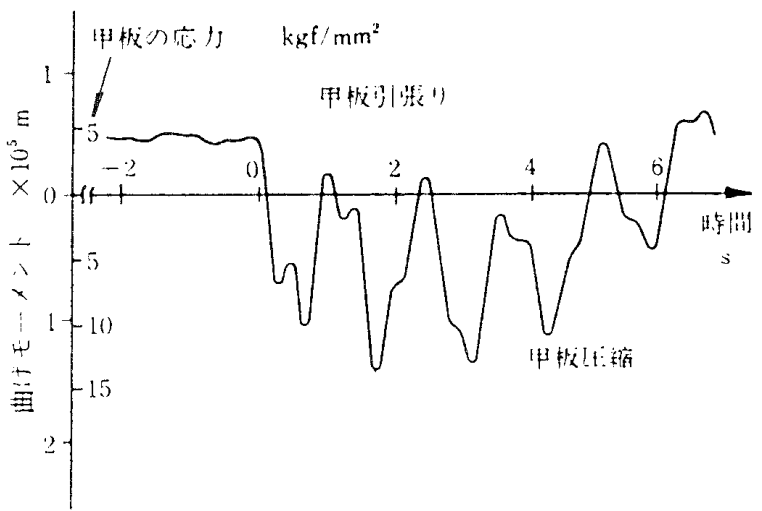

図 3 破断した断面に生じた曲げモーメント の時刻歷（時刻は図 2 と同じ）。 
ゆろスラミングによる衝撃圧力が生じ, 船体に過 渡的な振動が起こり，船に大きな曲げモーメント が発生する可能性があることになる，船長の説明 に基づき波の形を仮定して，スラミングの影響を 考慮した理論(5)によって計算した波の状況と船の 姿勢の関係を図 2 に，切断した断面に生ずる曲げ モーメントを図 3 に示す。この曲げモーメントて はスラミングによって生じた振動成分が大きな部 分を占めており，スラミングを考慮しなければ甲 板に圧縮応力を生じさせる曲げモーメントの最大 値ははるかに小さくなる。

有義波高は，波高の $1 / 3$ 最大平均に相当しその 海域の平均的な波高である。従来，波の性質は不 規則であるとして, Rice 以来の不規則振動の理論 と，多くの観測によって得られた波のエネルギ・ スペクトラムに基づいた波浪の統計理論が広く用 いられてきた。しかし，船長の説明による事故発 生時の波の形は，規則波に近いうねりに支配され たものであった，形状が規則波に近く，波長が船 の長さ程度の波の中では，スラミングが起こりや すく，スラミングが生ずると大きな曲げモーメン トが発生するのである。

\section{3. うねり}

風が吹くとその粘性によって海に波を起こす。 このような波は風波，wind sea と呼ばれ不規則 で，いろいろな波長の成分波の合成したものと考 えられる。海の波には分散性があり，成分波の伝 ぱ速度は波長の平方根に比例するので, 風波の中

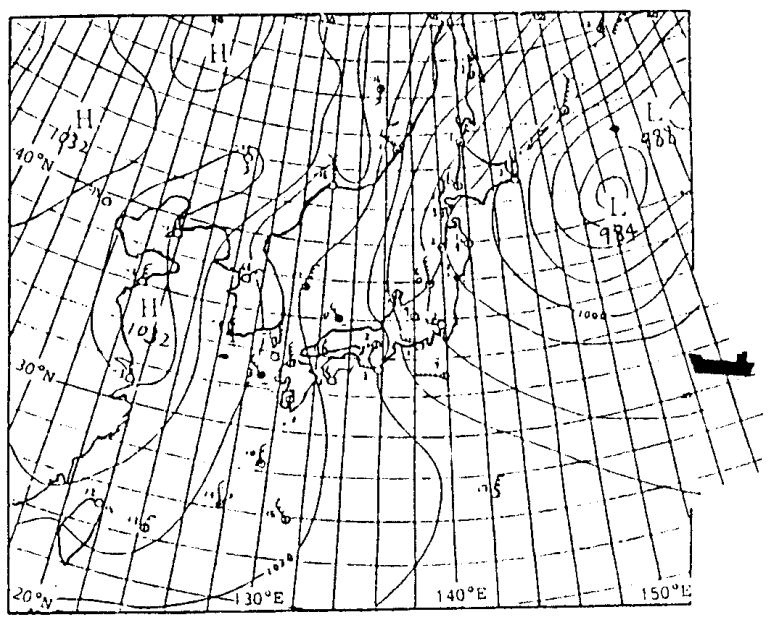

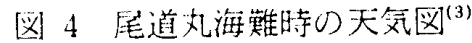

の長波長の成分は風の吹いていない海域に早く出 てしまう。この際，この長波長の成分は，短波長 の成分のエネルギを吸収して成長し，うねり， swellといわれる。よく知られている「土用波」は， 南方洋上で台風などによって起こされた風波から 発達したうねりが伝ぱしてきたものである。した がって，海洋で遭遇する波は，その海域の風によ つて生じた風波と遠方で生じたうねりよりなって おり，前者は波長が短く不規則であり，後者は波 長が長く，带域のごく狭い不規則波（したがって 規則波に類似している）と考えられている。

さきの尾道丸の場合は，風波の有義波高心 $3 \mathrm{~m}$ といわれており，波はほとんどうねりによって支 配されていたことになる。このとき，中国中部に 居座った高気圧によるいわゆる「大西風」と北方 低気压によって生じたと思われる2系統のう机り があったことが，図 4 ，应 5 に示す当時の天気図 と気象静止衛星「ひまわり」の每真からも推定で きる。図中船印は遭遇位㯰である (1) (3)。

「魔の海域」とはうねりが卓越した海域のようで ある。しかもうねりは遠方の海域の風によって起 こり，その山岋あまり崩れないので, 過小評価し がちである。

\section{4. 座屈による破壇}

スラミングが起こると船首部の船底が衝䡔的な 圧力をうける。このため，船首部の甲板に烷生す る压縮応力は引張応力より大きくなる，中立軸の 位置が断面の深さの中央より低いことにより，船 の断面の支える最大曲げモーメントは甲板の座屈 によって支配される。このような䡛情によって尾 道丸の場合，甲板に広範画に座屆が生じたようで

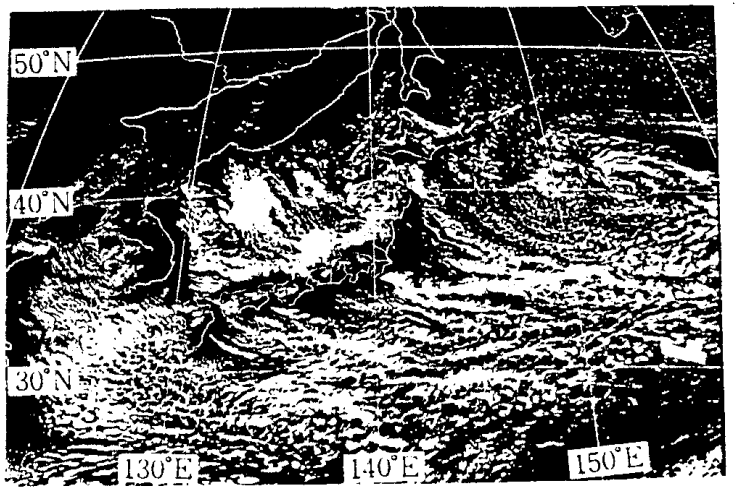

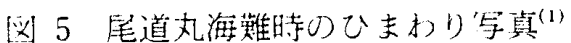


ある。スラミングが生じ，船首が波に突込み，京 たたび浮上したときすでに船首が約ゔ上向きに 折れ曲がっていたという。この上き甲板隹座届変 形に伴う大きな塑性変形をうけたはずである。相 ついでくる波によって船首部か上下にゅれ，引張 り・压縮の大きな塑性変形が繰返され，甲板が切 断したと思われる。そのあと船首部が大きく上问 きに折机曲がり，最後洨机じれて全断面が切断し たという。事実船底部の板仗じ切れたような様 子が詳細な写真からうかがえた。最近の研究によ ると，最初に大きな座屈変形などにより塑性変形 をうけた部材に対し，続いて引張り圧縮が繰返さ れると容易に切断することがわかった。本船心場 合がまさにその状態であったと思われる。このこ とは，平板構造物に座届が生ずると切断する可能 性があることを示している。切断が生ずろのは大 きな引張力あるい缲返し荷重に上る披労の場合 だけではなことに注意を要する。

\section{5. 危険海域}

以上によって異常海難がスラミングに倬係した 晲象であり，スラミングは規則的なう机りによっ て起こりやすいことがわかった。したがって，大 きなうれりの発生する海域をさけて航行するとこ のような状況は生じないことになる。大きなうね りの発生するのは日本近敏に拀いては(3),

（i）台風・低気压の通逍後の海域，とくに進 行方古の右後方。

(ii）冬期の大西風と北方低気压に上る影集。

(iii) 寒冷前線（不連続線）を伴う低氛圧前 線上。

2 方向以上の方向からうねりや風波がくると，重 畳して大きな波高を示すことがある。このような とき三角波といわ机る（iii）の場合三角波が多発 する。このほか，海流などによって波高が著しく 壃幅されることがある。

異常海難はこのように限られた海域だけに発生

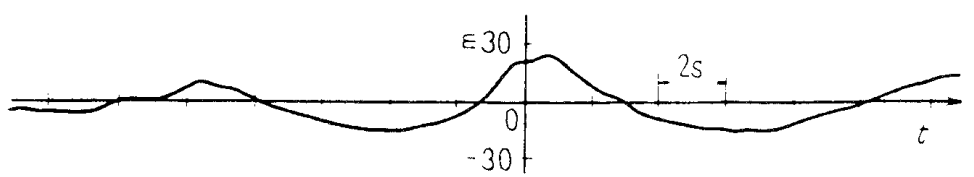

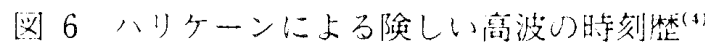

するのだから，船の安全のたかにはこのような危 険海域を避计て航行寸ればよい。建筑物と異なり， 船の環境仕乗組員の半断で変えることができるの である。

この場合やっかいなのは，低気圧なとの移動に より危険な海域が速やかに移動することである。 しかもその移動速度は船速上り早い。いつたん危 険海域に人り込古と，そ心海域から離脱できない ことがある。しかし，危険海域に入り込まないこ と, 入ったなら洨早く離脱することが船の安全の ため心最善の方法である。このためには海象子報 が役立つことはもちろんである。

\section{6. 荒天航法}

現在の海象子報システム仗，船からのの通報に基 ついているので，時間的遅れがあり，そのために 危険海域に入り込む可能性がある。また，危険海 域を回避すべく努力しても，最近の低馬力の省工 ネルギ船では必要な速力で航行できず，やもを得 ず荒天に遭遇することがある。ここで荒天とは， 波浪の激しい状況をいうが，多くの場合同時に風 も激しい。

図6はアメリ力沿岸繁借隊の援助に上って実测 されたハリケーン中の波高の時系列である(4). 海 波は分散性をもつため，この国は波の形状を表与 わけではないが，波長 $=170 \sim 330 \mathrm{~m}$, 波高 $=20 \mathrm{~m}$ のうねりと推定できる。この波は規則波とはいえ ないにしても，かなり規則性をもっている。この ようなう权りの台何目視あるいはレーダで確認 でる。

荒天時に巽常海難が発生しないためにはスラミ ングが生じないように操船すれいばよい，スラミン グは船が大きなピッチング・ヒービングを行って， 船首部心波面に刘与る相对連動が激しくなるとき に起こる。このような状態は船の波に対する出会 い周期がピッチングとヒービングの固有調期（両 者はほぼ等しい）に近いときに生ずるので，ビッ チング・ヒービングが激しく起こるとをは， 減速与るか針路在変えて船と波心出会い周期 を変えれいばスラミングは起こらなくなる。注 意しなけ札な゙なないのは，針路を变えたと きローリングが大きくなる可能性りあること 
である。たとえば波に向かって航行（逆走）して いるときスラミングが起こるならば，針路を反転 (順走)して, 全速力で航行す机ばスラミングは起 こらないであろう．針路を変えるとき大きなロー リングが起こると乗組員の心理に悪いし，実際風 向きとの関係で転覆のおそれがないとはいえな い.このような処置は慎重かつ果断に行わなけれ ばならない。

このような場合の判断の助けになるのは，スラ ミングが船のピッチング・ヒービングという劍体 運動に関係していることである。したがってピッ チングなどを計測しておう，それがあるいき值を こえたとき，適当な処㯰をとればよい，海象の変 化は，津波の場合と異なり，急激に起こることが ないのでこれで十分な゙はずである。いき值をこえ る可能性の有無の判断は計算機にやらせてもよ い. 計算機が最適の操船法を指示してくれるよう になることが関係者の目標である(3).

\section{7。構造強度}

異常海難は構造強度に関俰した事故であるにも かかわらず，以上の䚽論に扔いては構造強度の重 要性を無視しているかにみえる。波の状況を指定 すれば，船の楧造をその波に耐えるように設計す ることができる、スラミングは非線形現象なので， 波をわずか変えるとその状況が著しく変わること もあり得る。そ机え規潐的な波に対するスラミ ングに耐え得るということは実際上意味がない。

したがって，通常の状態すなわち線形的に取扱 える範囲内で十分な強度をもつように設計してお き，スラミングのような゙非線形的な現象が発生し ない上うに船を運航するというのがひとつの解決 法であろう。このとき, 前述のピッチング, ヒー ビンクに刘するいき値の炔定には，船の積荷状況 などとともに，船の形状と強度が重要な関係をも つことは明らかである。したがって船の形状を衝 㧛力が発生しにくい上うに選び，かつ強度の水準 を高好て㧍けば，操船の自由度が広がる。

\section{8. その他の異常な海難}

以上に打いては船体が波によって真二つに折れ
るという事故を中心に考察した。構造上の大事故 にはこのほかの形式もある。

（i）尾道丸の事故の直後起こった船首部の外 板が脱落した事故は新聞にも報じられた。畳 4 万 枚ぐらいの大きさの防とう材つきの外板が波の衝 撃圧力によってつぎつぎ落ちたといわれる。衝 揧圧力はスラミングによって発生したと考えられ ろ、板にかなりの腐食が見られたが，机影響も あると思われる。

(ii） スラミングによっては尾道丸のように船 首部が上向きに折れ曲がるが，空荷で喫水の浅い 状態ではスラミングによる衝撃压力が中央上りに 加わり，への字形に折れ曲がった例がある。本船 は小形船で，船首部に喫水を深くするためのバラ スト水を積んでいたことが関係したものと思われ ろ.

(iii）船首部の外板にフレアと呼ばれる円弧状

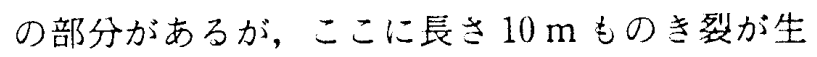
じた，同時に本船の船首部全体が異常に机じられ た。このような事故を防ぐためには構造部材の寸 法を十分に增せばよい。またフレア部の形状を変 え，スラミングによって，この部分に発生する衝 㲗压力を小さくすることもうひとつの方法であ る。それには船の中心面に対するフレア部の角度 を小さくすればよい。

これらの事故も，前に述べた場合と同様にスラ ミングによる衝揧圧力の発生がなけ机ば起こらな いはずである。（i ），(iii）の場合は衝揧圧力の発 生の範囲が局所的な場合であるため, さきに述べ た荒天航法では不十分であることが知られてい る.(iii) の例では衝撃圧の発生を避ける目的で波 を, 船の進行方向から $30^{\circ}$ の向きから受け, この事 故が起こった。一般に $30^{\circ}$ の変針は不十分なよう に思われる，上の例ではむしろ正面から波をうけ たほうが衝撃圧が小さかったとの理論的な結論も 得られている。

かりふ扔るにあ丸は, 図 7 に示す不連続線上で 事故を起こした ${ }^{(3)}$.ここでは 2 方向からの風波お よびうねりを受け，これらが重畳したいわゆる三 角波が起こっていたはずである。本船は異常な大 波によって船首部が破壊されたといわ机ている が，船の運動によって衝撆力が格段に增大された 可能性もある。 


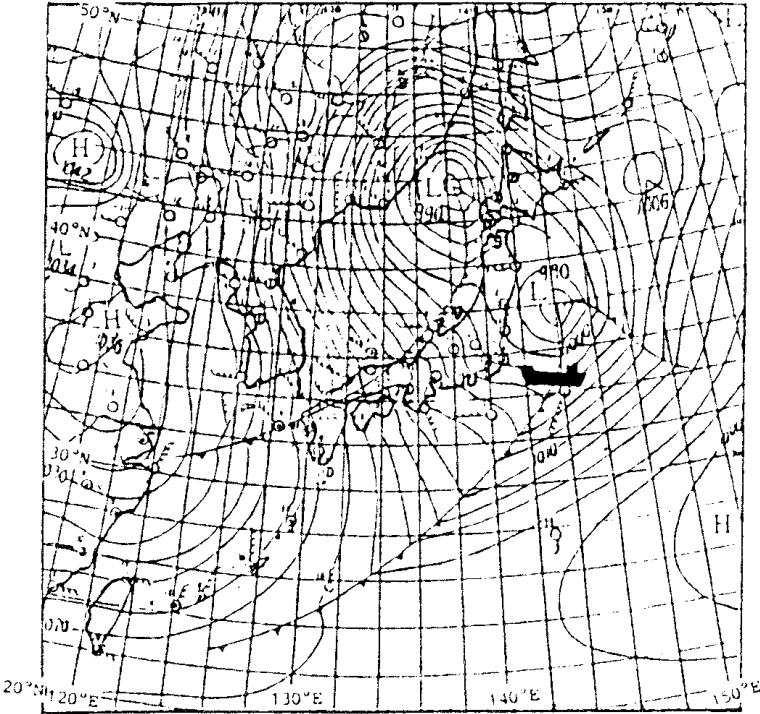

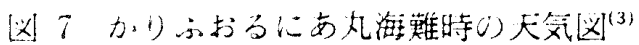

\section{9. おわりに一一安全のために一-}

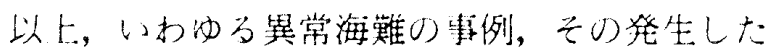

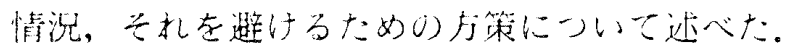

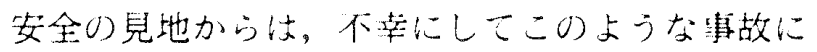

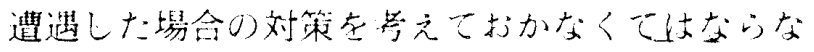
w。

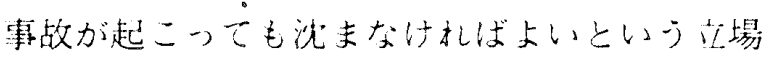

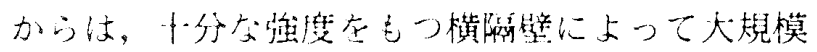
な没水防ぐことが必装である。大形船ではこ0 刘策は一応と的ていると考えてよい。

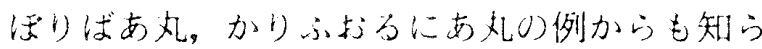
れるように，事故が㨁ちに沈没につながる四能性 がある。このため船是の安全な脱出のための年策 として，現状の救命ボートと救命いかだによる方

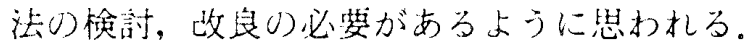

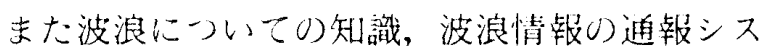
テムなどまな゙不卜分な面が多いように偲われる。 近い将来人上衛等に上る波浪情報が則時に人手で きるようになると，尼陨海域り確認上特前り避航 に㤌ひじょうに有力な乎段になると思う。そのよ うになっても，局听的な海域し情沈は船と相刘的
に判断されなけれ格ならないので，その適切な荒 天航法のための補助システムが必要である。

波浪について，その発達に関する研究仙多いが， 船の強度に関係するうねりの成長のような波の衰 退期に関する研究が不足の上うに思われる。これ が波浪情報に対する判断に欠かせないはずであ る.

異常海難注，船の設計と安全に対する装俑，波 浪情報，危険水域の回避と荒天航法，船の適切な 保守，㐘組員の訓練と学兒によって未然に防いこ とができるのである、海難統計と個々の船の安全 と沬直接の関係流ない。

最後仿船長の操船に対する決断と奏行である。 いろいろな情報は判断の一助にはなるがそれ以上 のものでない．船の運航の責任者という立場もあ る。しかもその决断は短時間で行わなければなら ないのである。船長の全人格が船の安全を支えて いるといって過言でなな。

造船篹係者が安全性の高い船を供給し，船社が 船り保全に万全をつくし，気象器係者が海象に関 する正確な情報を早期に提供し，船長をはじめと する兵組買が適切な運航・操船を行うならば船の 安全は保た机る。

船の青全が一歩前進することを期待して榴筆す 3.

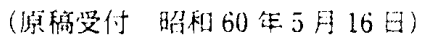

\section{文献}

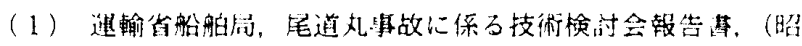
$56-11)$.

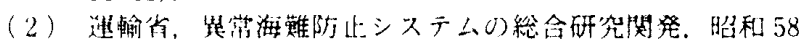
年没教告其，(昭 59-3)。

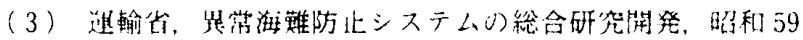

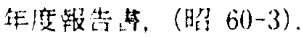

(4) Buckley, W.H. A Study of Extreme Waves and Their Effects on Ship Structure, SSC-320, (1983). U.S. Coast Guard Headquarter.

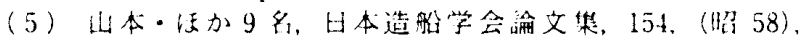
516. 